\title{
Engineering Geological and Geotechnical Approaches for the Construction of Powerhouse Cavern of Tehri Pumped Storage Plant (1000 MW) - A Case Study
}

\author{
Rajeev Prasad and Nishith Sharma
}

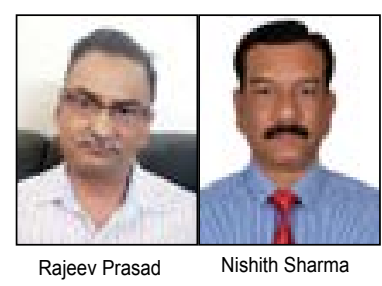

Abstract Construction of underground Cavern in the Himalayan region is full of challenges and uncertainties. Experience has shown that construction in Himalayan regions requires good understanding of geology, adequate site investigations, proper design and selection of suitable construction methodology and technology. The most commonly encountered geological problems during excavation of underground structure in Hydroelectric Projects are, Fault/Thrust/Shear Zones squeezing and swelling, wedge block failure etc. Tehri Pumped Storage Plant (PSP) is located at the left bank of river Bhagirathi in the state of Uttarakhand in Northern India. This case study indicates about the geological challenges faced and their remedial measures during the construction of Tehri PSP Powerhouse Cavern having dimension of $203 \mathrm{~m} \times 24 \mathrm{~m} \times 58 \mathrm{~m}$.3D-geological mapping with 1:100 scales was carried out in excavated central drift of powerhouse to evaluate the rock composition, behavior of rock mass, structural features and further investigation to finalize the layout and orientation. During the investigation Sheared Phyllite with bands of thinly Phyllite Quartzite rock were encountered in the end portion of central drift of powerhouse which had posed a mammoth challenge in designing the powerhouse cavern. Keeping in view the recommendations of geotechnical experts and the design consultants, decision were made to shift the cavern further by $50 \mathrm{~m}$ to avoid Sheared Phyllite bands. The shifting of cavern led to the reorientation of structures like control room, service bay and location of units etc. This paper briefly describes the Engineering Geological and Geotechnical set up of powerhouse with proper investigation approaches and excavation sequences highlighting the importance of orientation and Sheared Phyllite Zone.

Keywords: Powerhouse, Geological and Geotechnical investigation, Sheared Phyllite, Excavation Sequence, Tehri PSP, India

\section{Introduction}

The 1000 MW Tehri Pumped Storage Plant (PSP) is 1 part of the 2400 MW Tehri Hydropower Complex being built on the river Bhagirathi in the Indian state of Uttarakhand; falling between $78^{\circ} 30^{\prime}$ and $79^{\circ} \mathrm{Oo}{ }^{\prime} \mathrm{E}$ longitudes and corresponding $30^{\circ} 30^{\prime}$ and $33^{\circ} 30^{\prime} \mathrm{N}$ latitudes (Figure1).

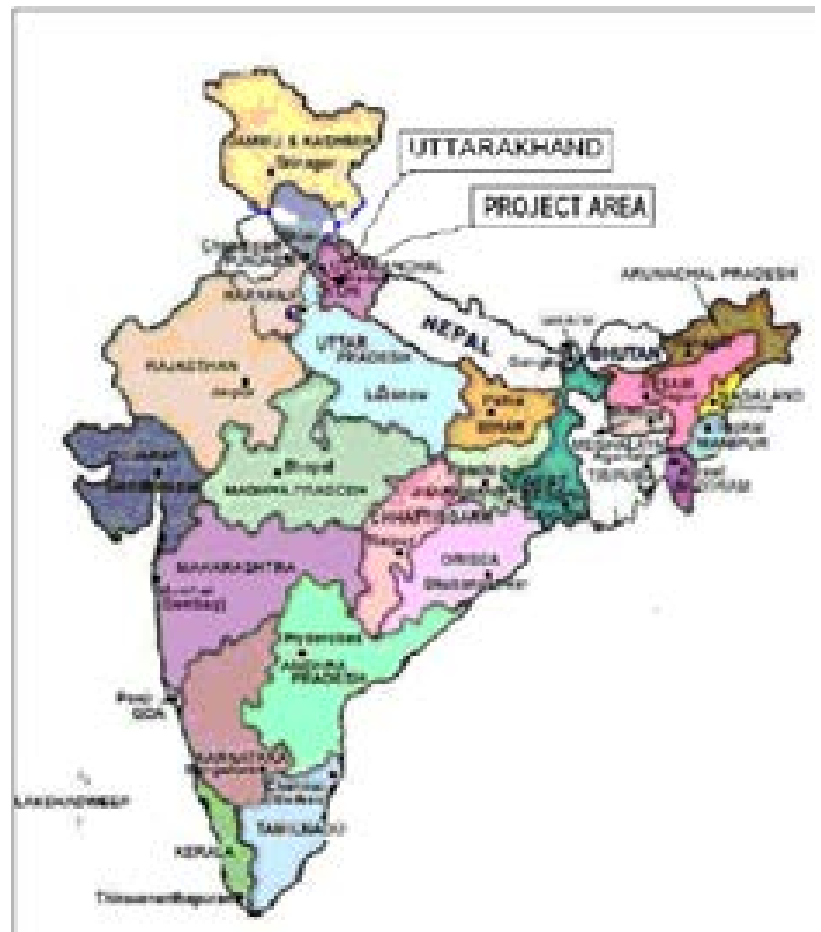

Figure1: Showing Location of Project area
The nearest rails head is Rishikesh which is located approximately $82 \mathrm{~km}$ south of the project site. It will be a peaking power plant located between the Tehri and Koteshwar dams, which are also the part of powerhouse complex. The PSP is being developed by THDC India Ltd, a joint venture of Central Government and the State Government of Uttar Pradesh (UP).

Tehri Pumped Storage Plant, comprising four reversible pump turbines units of $250 \mathrm{MW}$ each, involves construction of an Underground Machine Hall on the left bank of river Bhagirathi. The main feature of the Project is the large variation in head, of about $90 \mathrm{~m}$, during the maximum and minimum discharge period, under which the reversible units shall operate. The operation of Tehri Pumped Storage Plant is based on the concept of recycling of water discharge between upper reservoirs to lower reservoir. Tehri Dam reservoir shall function as the upper reservoir and Koteshwar reservoir as the lower balancing reservoir (Figure 2).

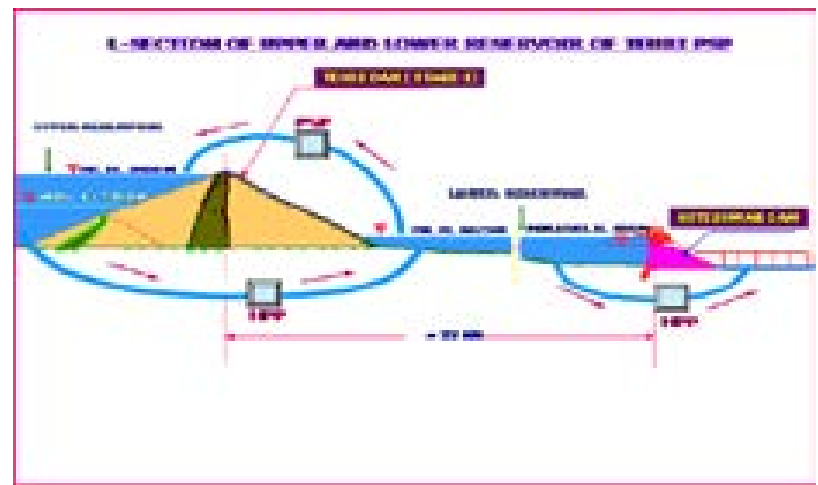

Figure 2: L Section of Upper and Lower Reservoir of Tehri Pumped Storage Plant 
The pumping of water requires 1712 million units (MU) of power during off- peak times. The main purpose of Tehri PSP is to stabilize the grid at Tehri Hydro Power Plant (HPP). It ensures that there is no shortage of head at HPP during dry seasons. In non-peak hours, the water will be pumped back to the upper reservoir by utilizing surplus power available at the grid.

Design and construction of any underground structure in Himalayan region requires thorough knowledge of regional geology and geotechnical approaches in a time bound and cost-effective manner. Himalayas are the youngest mountain chains undergoing orogenic and structural deformation. The geology of this region is relatively complex and varying in nature. In some cases, the hostile geological conditions are unforeseen and it is also a fact that a paucity of investigation leads to exaggeration of the problems. It is important to study such cases and device strategy for future development. The role played by various geological and geotechnical investigation in firming the successful implementation of any Hydropower scheme is crucial (Khanna et.al. 2016). Evaluation on the stability condition of an underground powerhouse cavern is a challenging issue from the Rock Mechanics point of view, location, orientation, size of cavern, complexity of access tunnels and geological conditions are some important issues among other boundary conditions. These challenges increase exponentially while planning underground excavation in the Himalayan region where rock mass is heavily influenced with tectonic movement (Panthi, et. al. 2012).

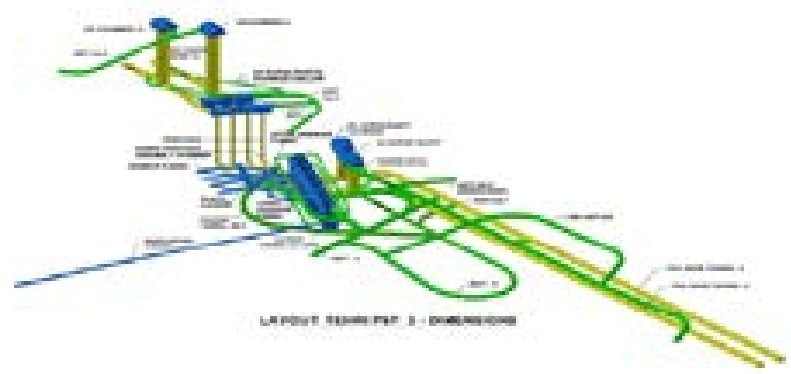

Figure 3: Three-dimension view of Powerhouse complex of Tehri Pumped Storage Plant

Tehri Pumped Storage Plant is under construction and is being executed by $\mathrm{M} / \mathrm{S}$ Hindustan Construction Company Ltd. under EPC mode. The major Project components are Powerhouse Cavern, upstream and downstream shafts, Butterfly Valve chamber, penstock assemble chamber, and a pair of tail race tunnel and outlet structure. Several geological and geotechnical issues were discussed to finalize the location and dimensions of Tehri Pumped Storage Powerhouse Cavern. It has been further concluded that detailed geological and geotechnical investigation is required in terms of exploratory drilling; in-situ and laboratory tests and other geotechnical parameters (Panthi, et. al. 2017). It assesses and compares the displacement of cavern walls and extends of yield zone to toe slope, based on data collected from pre-construction phase engineering geological investigations. Three-dimension view of powerhouse along with its associated tunnels gives a clear picture as shown in Figure 3. This article deals with the specific type of underground cavern design and construction problems, namely stability assessment in Sheared Phyllite zone encountered at the end portion of central drift portion of powerhouse, as well as reorientation of structures like service bay machine hall and location of units.

\section{Regional Geological Setting}

Project site is within the Lesser Himalaya which lies tectonically between the Main Central Thrust (MCT) and the Main Boundary Thrust (MBT) respectively. The former separates Meta Sedimentary sequence of Lesser Himalaya to the north from Crystalline rocks of Higher Himalaya, and latter disjoin the lesser Himalayan sequence from molasses sediments of Frontal Fold Belt (FFB), in the south. Phyllites of Chandpur formation of Jaunsar group and Quartzites and Metabasics of Garhwal group are exposed along the project. Most prominent tectonic features, Srinagar Thrust lies $5 \mathrm{~km}$ north of the project and it crosses Bhagirathi River at Nalupani and Bhilangana River at Gadolia. Rock units are part of the low-grade metamorphic rock that has been thrusted, folded and deformed. There are two main tectono-stratigraphic units: the Krol Super Group and the Gharwal Group (R. Shankar et.al.1989). This former Super Group is subdivided into the Jaunsar Group and Krol Group. Jaunsar Group is found at the Tehri site and includes quartzites and phyllites in varying proportions that have undergone various phases of deformation leading to development of numerous tectonic dislocations, sheared zones, seams and joints of different scales and categories. Type of lithology categorized in the Tehri site have been classified during the dam and HPP design and construction by Geological Survey of India and same have been adopted for the PSP. The nomenclature has been based on variable proportions and quality of quartzite and Phyllite include: PQM Phyllitic Quartzite Massive; PQT - Phyllitic Quartzite Thinly Bedded; QP - Quartzitic Phyllite; SP - Sheared/ Shattered Phyllite.

PQM and PQT are more quartzite (arenaceous) and rarely micaceous in composition and are coarser in grain size. These rocks are grey, dark grey, brownish grey, grayish grey and green in color. It is mainly comprised of quartz, feldspar and oriented laths of micaceous minerals. QP is more areno-argillaceous in composition, fine grained and dark colored. SP comprises of argillaceous and deformed variants of $\mathrm{PQM}$ and $\mathrm{PQT}$ rock, formed in sheared zone area which has weak rock mass characteristics.

\section{Site Specific Geology}

The Machine Hall of Tehri PSP is under construction and located around 220m towards East of the existing Machine Hall and Transformer Hall of HPP. The lithological units $\mathrm{PQM}, \mathrm{PQT}$ and SP have been encountered in the central drift of powerhouse. The rock mass is foliated, bedded, jointed, slightly weathered and sheared at some places.

\section{Petrology}

Petrographic analysis (Note_EDT_GG_12-0178B GFR) have been carried out on 12 nos. of rock samples 
obtained from core holes(Report - Note EDT GG 120178C). Only two litho units have been revealed by the analysis :Quartzitic Phyllite and Phyllitic Quartzite. Their mineralogical compositions are very close; Quartzitic Phyllite presents a little less Quartz than Phyllitic Quartzite and little more Phyllo-Silicates like ChloriteMuscovite-Sericite.

\begin{tabular}{|c|c|c|c|c|}
\hline $\begin{array}{c}\text { R o c k } \\
\text { Type }\end{array}$ & Quartz & Chlorite & $\begin{array}{c}\text { Muscovite- } \\
\text { Sericite }\end{array}$ & $\begin{array}{c}\text { Ferruginous } \\
\text { Material (iron } \\
\text { oxide and sul- } \\
\text { phurs) }\end{array}$ \\
\hline $\begin{array}{c}\text { Phyllitic } \\
\text { Quartzite }\end{array}$ & $55-65 \%$ & $18-23 \%$ & $10 \%$ & $2-7 \%$ \\
\hline $\begin{array}{c}\text { Quartz- } \\
\text { itic Phyl- } \\
\text { lite }\end{array}$ & $50-60 \%$ & $15-26 \%$ & $12-18 \%$ & $2-7 \%$ \\
\hline
\end{tabular}

Table 1: Indicates Mineral Compositions in various grade of Phyllititic Rock

The rock consists of a fine-grained rock, mainly made of Quartz, Chlorite, Muscovite/Sericite and ferruginous material. Color of the rock is light grey to dark grey. Foliation in the rock is defined by parallelism of flaky minerals like Muscovite and Chlorite. There are a few flakes of Muscovite and Chlorite which are across the prevailing foliation. Most of the Muscovite flakes are altered to Sericite. Quartz occurs as stretched grains along foliation as well as discrete grains across the foliation, randomly oriented(Table-1). The latter quartz grains (secondary quartz) may be as a result of replacement filling. These Quartz grains make the rock hard and compact. A significant quantity of Quartz grains (20 to $30 \%$ of the total amount of the Quartz in the rock) appear to be strained or with an undulating extinction angle under polarizing light.

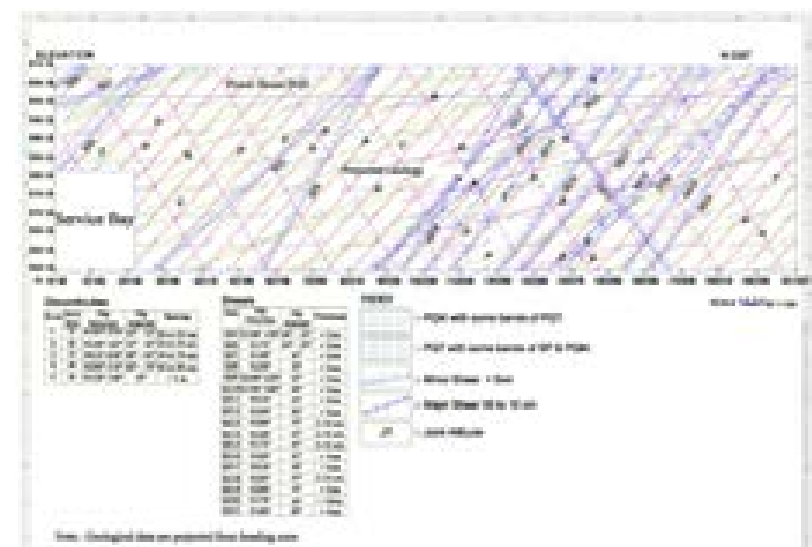

Figure 4: Geological Section along already excavated Central drift of Powerhouse

\begin{tabular}{|c|c|c|c|c|c|c|c|c|}
\hline $\begin{array}{l}\mathrm{S} \\
\text { No. }\end{array}$ & $\begin{array}{l}\text { Name of } \\
\text { Core Hole }\end{array}$ & $\mathrm{Rd} /$ Location & $\begin{array}{l}\text { Size of Hole } \\
\quad(\mathrm{mm})\end{array}$ & $\begin{array}{c}\text { Length of } \\
\operatorname{Hole}(\mathrm{m})\end{array}$ & $\begin{array}{l}\text { Angle with } \\
\text { Horizontal }\end{array}$ & $\begin{array}{l}\text { Start date of } \\
\text { Core Hole }\end{array}$ & $\begin{array}{l}\text { Finish date of } \\
\text { Core Hole }\end{array}$ & Remarks \\
\hline 1 & $\mathrm{CH} 22$ & $315.00 \mathrm{~m}$ & \multirow{2}{*}{$76(\mathrm{NX})$} & 53.00 & 65 & 30-July-11 & 14-Aug-11 & \\
\hline 2 & $\mathrm{CH} 23$ & $145.00 \mathrm{~m}$ & & 53.00 & 60 & 19-Aug-11 & 30-Aug-11 & \\
\hline 3 & $\mathrm{CH} 20$ & $190.00 \mathrm{~m}$ & \multirow{3}{*}{$38(\mathrm{EX})$} & 30.00 & 45 & 12-Aug-11 & 19-Aug-11 & \multirow{3}{*}{$\begin{array}{l}\text { These core holes } \\
\text { drilled in three dif- } \\
\text { ferent directions for } \\
\text { HTPF. }\end{array}$} \\
\hline 4 & CH19 & $190.00 \mathrm{~m}$ & & 30.00 & 45 & 20-Aug-11 & 24-Aug-11 & \\
\hline 5 & $\mathrm{CH} 18$ & $190.00 \mathrm{~m}$ & & 30.00 & 45 & 5- Aug-11 & 11-Aug-11 & \\
\hline 6 & $\mathrm{CH} 24$ & $260.00 \mathrm{~m}$ & \multirow{10}{*}{$76(\mathrm{NX})$} & 70.00 & 60 & 15 -Feb-12 & 05-Mar-12 & \\
\hline 7 & CH61 & $\begin{array}{l}\text { Left side of drift at } \\
\text { Rd: } 210.00 \mathrm{~m}\end{array}$ & & 12.00 & 180 & 03-Jul-12 & 05-Jul-12 & \\
\hline 8 & CH62 & $\begin{array}{l}\text { Right side of drift at } \\
\text { Rd: } 210.00 \mathrm{~m}\end{array}$ & & 12.00 & 180 & 05-Jul-12 & 07-Jul-12 & \\
\hline 9 & CH63 & $\begin{array}{c}\text { Upward of drift at } \\
\text { Rd: } 210.00 \mathrm{~m}\end{array}$ & & 12.00 & 90 & 07-Jul-12 & 11-Jul-12 & \\
\hline 10 & CH64 & $\begin{array}{c}\text { Downward of drift at } \\
\text { Rd: } 210.00 \mathrm{~m}\end{array}$ & & 12.00 & 0 & 12-Jul-12 & 14-Jul-12 & \\
\hline 11 & CH65 & $\begin{array}{c}\text { Upward of drift at } \\
\text { Rd:325.00m }\end{array}$ & & 9.00 & 90 & 17-Jul-12 & 19-Jul-12 & \\
\hline 12 & CH66 & $\begin{array}{c}\text { Downward of drift at } \\
\text { Rd:325.00m }\end{array}$ & & 11.00 & 0 & 20-Jul-12 & 25-Jul-12 & \\
\hline 13 & CH67 & $\begin{array}{c}\text { Left side of drift at } \\
\text { Rd: } 325.00 \mathrm{~m}\end{array}$ & & 12.00 & 180 & 25-Jul-12 & 27-Jul-12 & \\
\hline 14 & CH68 & $\begin{array}{l}\text { Right side of drift at } \\
\text { Rd:325.00m }\end{array}$ & & 9.25 & 180 & 27-Jul-12 & 29-Jul-12 & \\
\hline 15 & $\mathrm{CH} 25$ & $317.00 \mathrm{~m}$ & & 32.00 & 60 & 06-Sep-12 & 15-Sep-12 & \\
\hline
\end{tabular}

Table 2: Details of Core Holes executed at different location in Powerhouse 
Geological mapping carried out at the central drift of powerhouse indicates the real picture of lithology and its litho contact. It has also been observed that the cavern was pierced through thinly Foliated Phyllitic Quartzite (PQT), Massive Phyllitic Quartzite (PQM) and Sheared Phyllite (SP) medium to fine grained, grey, silicified at places. The dip of primary bedding and foliation were recorded to be $\mathrm{N} 180^{\circ}-220^{\circ} / 45^{\circ}-55^{\circ}$ and $\mathrm{N} 130^{\circ}-170^{\circ}$ $/ 35^{\circ}-45^{\circ}$ respectively. Mainly NE and NW dipping joints other than bedding/foliation joints were recorded in the entire area as shown in Geological section (Figure 4).

Based on Geological section, it has been observed that PQT + SP encountered at the end portion of central drift may possess the difficulties to establish the cavern. To finalize the dimensions and orientation, a detailed Geotechnical investigation was carried out to obtained Geotechnical properties and behavior of rock mass.

\section{Geotechnical Investigation \\ Drilling of Core Holes}

Sub-surface exploration for any underground structure is done by drilling core holes at different locations along the proposed alignment of structure. Total 10 nos. of drill holes have been made to investigate the subsurface condition \& behavior of rock mass. The details of core holes are mentioned below in Table 2 .

\section{In-situ and Laboratory tests}

In-situ tests carried out in the central drift of powerhouse at two different stages and details of investigation programme are as follows (Refer Table 3):

\begin{tabular}{|c|c|c|c|c|}
\hline $\begin{array}{l}\mathrm{S} \\
\text { No. }\end{array}$ & Location & $\begin{array}{c}\text { Test Descrip- } \\
\text { tion }\end{array}$ & $\mathrm{Rd} /$ Location & $\begin{array}{l}\text { No. of test } \\
\text { conducted }\end{array}$ \\
\hline 1 & \multirow{9}{*}{$\begin{array}{l}\mathrm{P} \text { o w e r - } \\
\text { house Cav- } \\
\quad \text { ern }\end{array}$} & PLT- 2 & $145.00 \mathrm{~m}$ & 1 \\
\hline 2 & & PLT-3 & $250.00 \mathrm{~m}$ & 1 \\
\hline 3 & & $\begin{array}{l}\text { PJT-4 with } \\
\text { MPBX }\end{array}$ & $210.00 \mathrm{~m}$ & 1 \\
\hline 4 & & $\begin{array}{c}\text { PJT-5 with } \\
\text { MPBX }\end{array}$ & $325.00 \mathrm{~m}$ & 1 \\
\hline 5 & & $\begin{array}{l}\text { Dilatometer } \\
\text { test in PJT-4 }\end{array}$ & CH61 to 64 & 8 \\
\hline 6 & & $\begin{array}{l}\text { Dilatometer } \\
\text { test in PJT-5 }\end{array}$ & CH65 to 68 & 8 \\
\hline 7 & & \multirow{2}{*}{$\begin{array}{c}\text { Dilatometer } \\
\text { test }\end{array}$} & ${ }_{\mathrm{CH} 23}^{\mathrm{CH} 22}$ and & 16 \\
\hline 8 & & & CH25 & 15 \\
\hline 9 & & HTPF & $\begin{array}{c}\mathrm{CH} 18, \mathrm{CH} 19 \\
\text { and } \mathrm{CH} 20\end{array}$ & 1 \\
\hline
\end{tabular}

Table 3: Details of In-situ tests Schedule

In-situ tests were performed including Plate jack test, Flexible Dilatometer test and Hydro-fracture test (HTPF). The objective was to define the deformation characteristics of the rock mass broadly classified into two categories, viz. "PQM+PQT" and "PQT+SP". The tests were conducted as per ISRM specification at Rd $210 \mathrm{~m}$ and $\mathrm{Rd} 325 \mathrm{~m}$, respectively in both the zones. The results were obtained in terms of deformation and elastic moduli for respective locations. The laboratory tests were also conducted to supplement the findings of in-situ tests. Location of geotechnical investigations are shown in Figure 5.

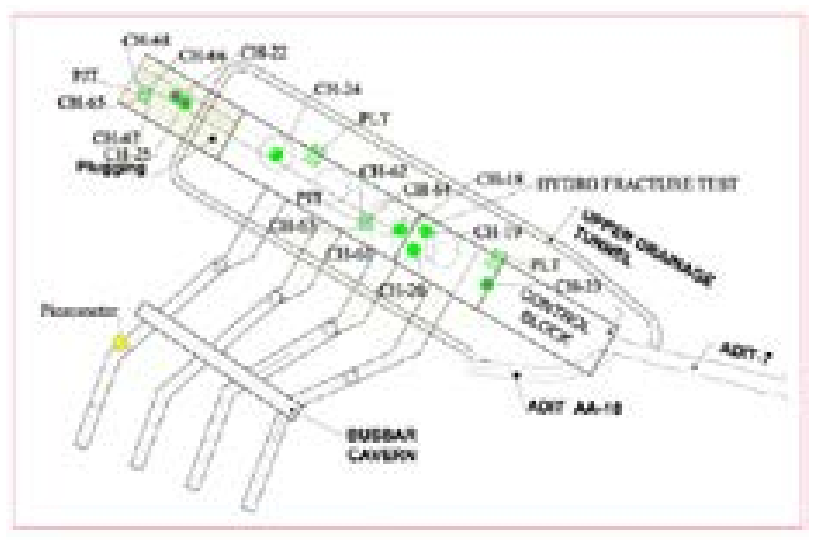

Figure 5: Location of geotechnical investigations in Powerhouse

On the basis of results obtained from geotechnical investigations, it has been decided that the position of service bay will be in between the machine hall \& control bay (i.e. similar to the Tehri HPP). Because of above said test report, the service bay was shifted by $53 \mathrm{~m}$ towards Adit 7. The Machine Hall center line and the water conductor system remained intact. Access tunnel to service bay (AA8) \& ventilation tunnel were realigned to be open in powerhouse at a new location shown in Figure 6.

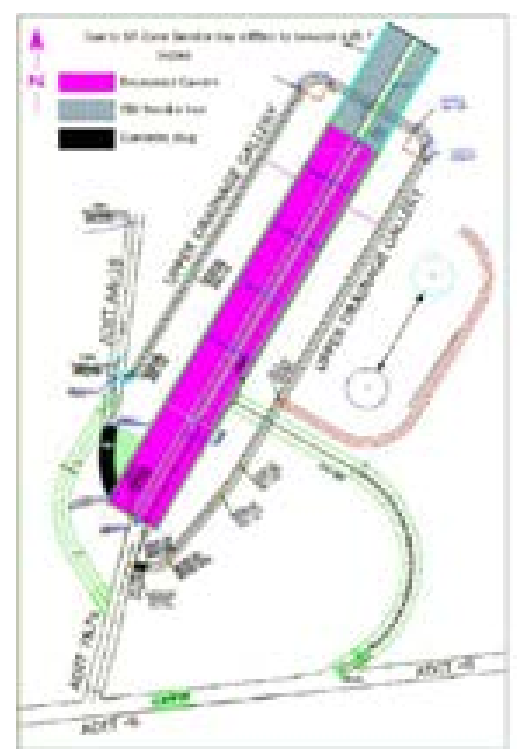

Figure 6: Location of new position of the Powerhouse

\section{Engineering Geological Mapping of Central Drift/ Central Gullet}

Three-dimensional geological mapping was carried out in central drift of powerhouse for a cumulative length of 203.om to suggest measures for rock support and to evaluate the tunnel stability as well as planning for further excavation. Fair rock mass was observed throughout the drift. Joint planes are rough to slightly 
rough in nature. Kinematics study was also done for all encountered joints (Figure 7).

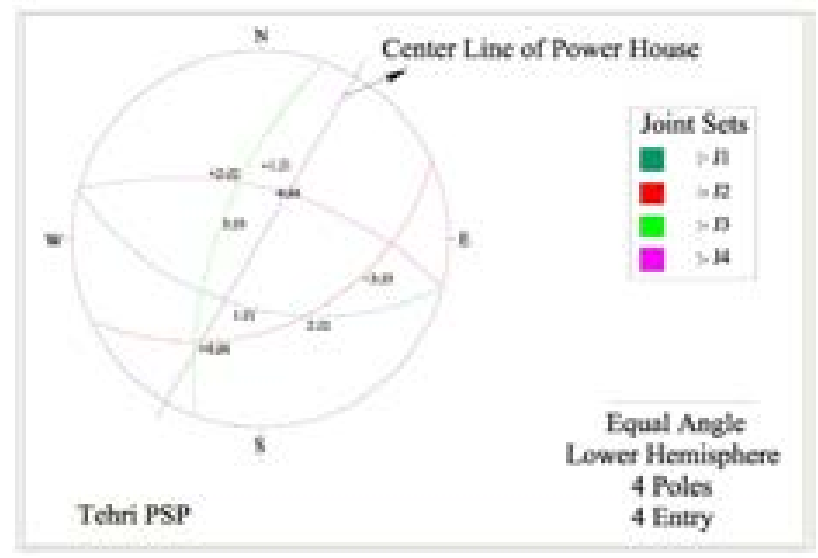

Figure 7: Lower Hemispheric Projection of Joint sets at Powerhouse

Dry to damp conditions were observed during excavation. Following joint sets were encountered during the excavation of central drift and side slashing. RQD ranges from 50-70\% and RMR value ranges in between 46 to 52 as mentioned in graphical representation of Figure 8.

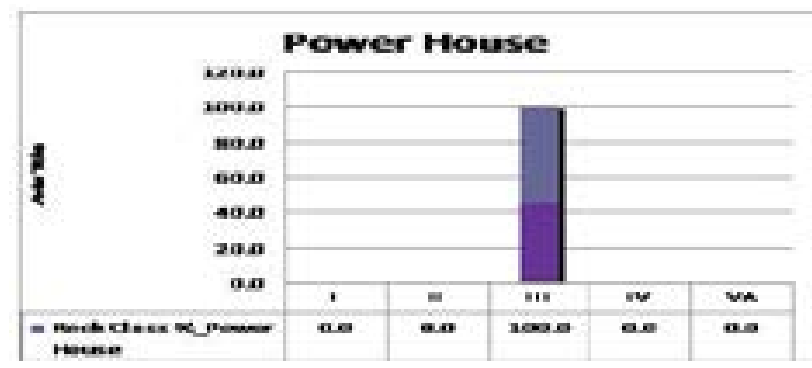

Figure 8: Percentage of Rock Class encountered during excavation of Powerhouse

\begin{tabular}{|c|c|c|c|c|c|c|}
\hline $\begin{array}{l}\text { Joint } \\
\text { Set }\end{array}$ & Dip/Amount & Persistence(m) & Aperture(mm) & Filling & Roughness & Weathering \\
\hline $\mathrm{J} 1$ & $\begin{array}{l}\mathrm{N} 180^{\circ}- \\
220^{\circ} / 45^{\circ}- \\
55^{\circ}\end{array}$ & $3-10$ & $\begin{array}{l}1-5 \mathrm{~mm} \& 0.1 \\
\text { to } 1.0 \mathrm{~mm}\end{array}$ & \multirow{4}{*}{$\begin{array}{l}\text { Soft }>5 \mathrm{~mm} \\
\text { to } \\
\text { Hard }>5 \mathrm{~mm}\end{array}$} & \multirow{4}{*}{$\begin{array}{l}\text { Rough to } \\
\text { Slightly } \\
\text { rough and } \\
\text { at some } \\
\text { locations } \\
\text { Smooth }\end{array}$} & \multirow{4}{*}{$\begin{array}{l}\text { Slightly } \\
\text { Weathered }\end{array}$} \\
\hline \multicolumn{2}{|l|}{$\mathrm{J} 2$} & $\begin{array}{l}\mathrm{N} 130^{\circ}-170^{\circ} / 35^{\circ}- \\
45^{\circ}\end{array}$ & $1-5$ & & & \\
\hline \multicolumn{2}{|l|}{$\mathrm{J} 3$} & $\begin{array}{l}\text { N010 } \\
65^{\circ}\end{array}$ & $1-5$ & & & \\
\hline \multicolumn{2}{|l|}{$\mathrm{J} 4$} & $\begin{array}{l}\mathrm{N} 280^{\circ}-310^{\circ} / 60^{\circ}- \\
70^{\circ}\end{array}$ & $1-3$ & & & \\
\hline
\end{tabular}

Table 4: Showing the details of joint sets in Powerhouse

\section{Methodology Adopted for the Construction of Powerhouse Cavern}

As per project profile, access tunnel to powerhouse crown was already excavated prior to award of work. Powerhouse excavation included widening of the central drift to form the arched crown of the Cavern followed by bench excavation. Powerhouse cavern has three main structures; Service bay, Machine Hall and Control building. Class-III Rock was observed throughout its proposed alignment. Total 31 Shear Zones were encountered in central drift of powerhouse and their thickness varied from $<5 \mathrm{~cm}$ to $10 \mathrm{~cm}$ filled with clay gauge and hard filling at some locations. After mapping and detailed Geological/Geotechnical investigation, side slashing of reoriented powerhouse was carried out followed by excavation and design support simultaneously.

\section{Upstream and Downs stream wall Slashing}

Upstream and downstream wall slashing was carried out with the help of control blasting throughout the length of cavern. Minor to major critical shear zone was mapped. The crown level of powerhouse is $\mathrm{El}$ : $610.16 \mathrm{~m}$ and slashing was done up to $\mathrm{El}$ : 557.00m. During the scaling of rock mass after the blasting, huge chunk of rock was fallen due to existence of Shear Zones and wedge failure at some locations. Considering the present scenario and past experience in the excavation of Himalaya's designs supports were provided without any delay. Class-III rock is observed throughout the cavern having RMR between 41 to 60. The major rock type encountered during excavation is $\mathrm{PQM}, \mathrm{PQM}+\mathrm{PQT}$, $\mathrm{PQT}+\mathrm{SP}$ as well as SP bands at lower elevation.

\section{Systematic Benching}

After successful excavation and support of powerhouse crown upto a level 602.00, benching activity was taken up. Each bench of $2 m$ depth was excavated and supported as per the design support till EL 590 was achieved. One-meter rock ledge on either side of the cavern was created by controlled blasting to support the crane beam at EL 592.40. Crane beam was casted during this period. To facilitate the movement of the crane and to shift hydro-mechanical and electro-mechanical parts during erection, the beam was secured by installing through pre-stressed anchors of 150 Ton capacity. The other end of the anchor emerged in the drainage gallery surrounding the powerhouse cavern where it was locked by hydraulic jacks. Further excavation upto EL 582.64 Roughness Weathering was carried out from the central drift cum Adit at EL: 602.00. Bus bars 5 to 8 , of 40.om length each, were also excavated during this period. Adit $8 \mathrm{R}$ to service bay and Adit 6C meets the powerhouse at EL 582.64. Benching upto 564.00 was carried out using Adit 8R and 6C. At EL 564.00, the lower horizontal penstocks meet the powerhouse, and at EL 555.00 the draft tubes intersect the powerhouse cavern. Muck generated from the pit and sump was finally removed from these two tunnels. Walls of the cavern were supported by installing 12.0 and $9.0 \mathrm{~m}$ staggered rock bolts with a 10omm thick layer of reinforced fiber shotcrete. Addition support in the form of $120 \mathrm{~T}$ cable anchors were provided on upstream wall between the Bus bar and lower penstock openings.

Systematic Benching was done throughout the 
cavern. Excavation beyond El: 602.0om will be carried out in various benches. Initially two benches of $2 \mathrm{~m}$ depth and remaining benches of $4 \mathrm{~m}$ depth have been considered for the excavation. Ramp is provided at El: 592.64 with the down gradient of 1:10 and extended with excavation to reach at various benches as well as for the movement of resources. The excavated muck handled via Adit 7A (Central drift of powerhouse). For the benching of control room machine hall and some part of service bay, Adit $6 \mathrm{C}$ is used up to El:582.0om and beyond $\mathrm{El}$ : $561.0 m$, excavation was taken up through lower penstock. At present, machine hall and control room are excavated up to El: 556.om. Design support system in terms of rock bolts and SFRS are also provided in this region.

\section{Rock Support System}

Cavities are mainly formed due to presence of shear zones. Most of the shear seams are major shears. A number of minor to major shears infilling with clay gauge and hard material have been encountered from the 3D Geological logs. Drainage holes are also provided in the arch and walls to release the water pressure and control the stability (Table-5)). Thickness of shear zone varies from $<5 \mathrm{~cm}$ to $10 \mathrm{~cm}$. Shear zone treatment with proper design methodology has been carried out. Details of support system installed during excavation of heading and benching is mentioned in Tabular form (Table-6)

\begin{tabular}{|l|c|l|}
\hline \multicolumn{2}{|c|}{ Elevation in $\mathrm{m}$} & \multirow{2}{*}{ Details of Drainage Holes } \\
\cline { 1 - 2 } From & To & \\
\hline 610.16 & 600.73 & $75 \varnothing 1.00 \mathrm{~m} \mathrm{C} / \mathrm{C}$ Staggered $6.00 \mathrm{~m}$ long \\
\hline 600.73 & 560.00 & $75 \varnothing 0.50 \mathrm{~m} \mathrm{C} / \mathrm{C}$ Staggered $6.00 \mathrm{~m}$ long \\
\hline
\end{tabular}

Table 5: Showing Details of Drainage Holes

\begin{tabular}{|c|c|c|}
\hline \multicolumn{2}{|c|}{ Elevation in $\mathrm{m}$} & \multirow{2}{*}{ Details of Design Rock support System } \\
\hline From & To & \\
\hline 610.16 & 600.73 & $\begin{array}{l}\mathrm{Fe} 50032 \varnothing, 1.50 \mathrm{~m} \mathrm{C} / \mathrm{C} \text { Staggered and alternate } \\
\text { length } 8.00 \& 11.00 \mathrm{~m}\end{array}$ \\
\hline 600.73 & 592.25 & $\begin{array}{l}\text { Fe } 500320,1.50 \mathrm{~m} \mathrm{C} / \mathrm{C} \text { Staggered and alternate } \\
\text { length } 9.00 \& 12.00 \mathrm{~m}\end{array}$ \\
\hline 592.25 & 590.00 & $\begin{array}{l}\text { Fe } 50032 \varnothing, 1.00 \mathrm{~m} \mathrm{C} / \mathrm{C} \text { Staggered and alternate } \\
\text { length } 9.00 \& 12.00 \mathrm{~m}\end{array}$ \\
\hline 590.00 & 560.00 & $\begin{array}{l}\text { Fe } 50032 \varnothing, 1.50 \mathrm{~m} \mathrm{C} / \mathrm{C} \text { Staggered and alternate } \\
\text { length } 9.00 \& 12.00 \mathrm{~m}\end{array}$ \\
\hline
\end{tabular}

Note: $200 \mathrm{~mm}$ thick SFRS applied after installation of Rock bolts on each and every bench throughout the Cavern

Table 6: Details of Support system installed in Powerhouse Cavern

\section{Crane Beam}

Powerhouse caverns are required to be equipped with very high capacity cranes for erection of turbines and generators during construction period and for maintenance in operation period. As a general design practice, the cranes are erected on beams supported by columns. In many cases, these structures are designed to be completely independent of the surrounding rock mass. In our opinion, this is an inappropriate design approach since it does not utilize the enormous carrying capacity of rock mass surrounding the cavern. The design of pre-stressed cable anchors required to support the beams follows the same procedure as would be used for the stabilization of wedges in the roofs or side walls of cavern.

The crane beams are normally cast in place when the cavern crown has been fully excavated and when the first bench has been taken. At this stage, about $50 \%$ of the displacement in the rock mass surrounding the cavern has already taken place. The displacements for each excavation stage can be estimated by numerical analysis. In the cavern of Tehri Pumped Storage Plant, corrosion protected pre-stressed cable anchors 150 Ton capacity was used directly against the rock face which is PQT and SP of reasonable quality. It was felt that the additional forces from the fully loaded crane could induce wedge instability in the walls. For this reason, the cast in place suspended crane beams were used for construction. Concrete columns were then added, once benching of powerhouse cavern was completed. Load cells were also installed in some of the anchors to know the behavior of rock mass and same shall be discussed separately in instrumentation part.

\section{Geological and Geotechnical Assessment of Powerhouse}

Details of geological and geotechnical assessment observed during excavation of powerhouse is as follows:

- Formation of unstable structural wedges due to intersection of $\mathrm{J}_{1}, \mathrm{~J}_{2}$ \& $\mathrm{J}_{3}$.

- Dampness to seepage is found at some place.

- A number of major and minor shears have been encountered along the entire excavated length.

- These shears have varying thickness $<5 \mathrm{~cm}$ to $10 \mathrm{~cm}$ along and across the bedding and foliation Joint.

- The rock mass has been intersected by two prominent set of joints, other than the bedding/ foliation joints, silicification along foliation joints, dipping towards $\mathrm{N} 130^{\circ}-170^{\circ} / 35^{\circ}-45^{\circ}$ was prominently recorded.

\section{Wedge Failure occurred at Rd: $\mathbf{- 5 2 . 0 m}$ in the} Cavern of Powerhouse Roof

Powerhouse at Rd: $-52.0 m$ where a wedge had fallen from the left crown of the cavern at the junction with existing Adit AA-10. The now defunct twelve numbers of steel rib sets which were installed as part of the support measures for the adit are now exposed after the widening of the excavation for the full cavern width. Some of the steel ribs understandably buckled due to the weight of big chunks of boulders which fall on them during wedge failure as shown in Figure 9. 

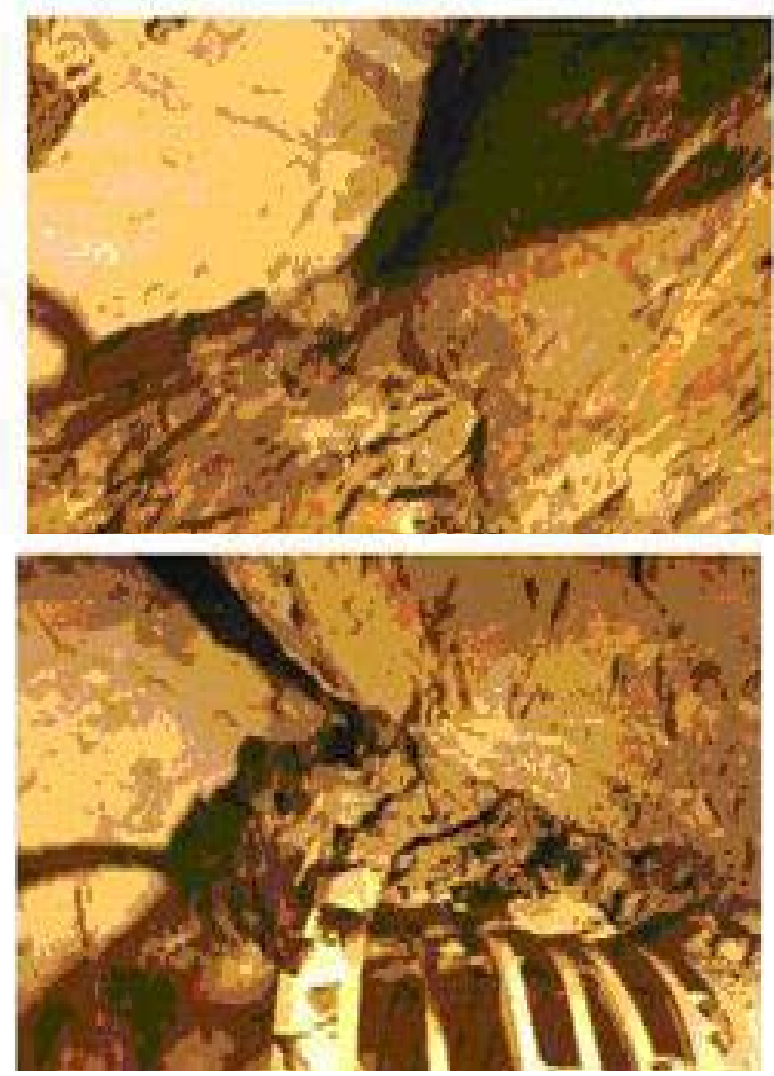

Figure 9: Front and Side view of over break Zone with exposed Steel sets of Ribs

\section{Probable Cause of Failure}

The southern end wall of powerhouse has been shifted by about 53.om due to existence of relatively large shear zone which crosses the cavern gallery at the northern end wall region. Due to this shifting AA-10 (Approach adit to Bus bar) now lying within the cavern top heading (refer Figure 10).

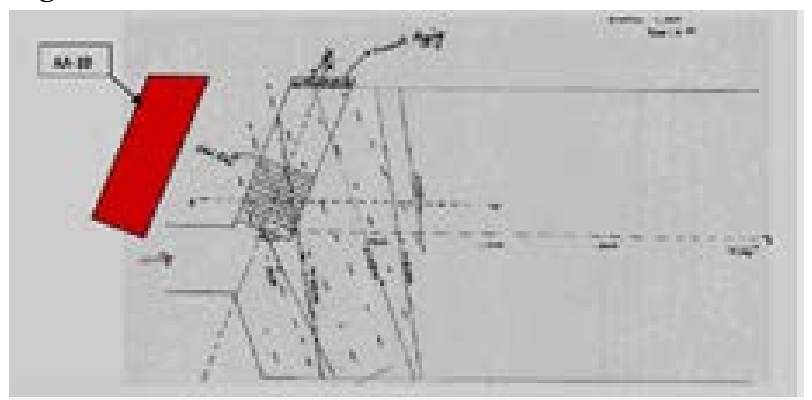

Figure 10: Crossing of Adit AA-10 within cavern layout

There are essentially three main joint sets which contribute to the wedge failure, J1, J4 and $\mathrm{J}_{3}$, J1 are major joint sets which are observed to traverse the entire cavern width. These joint sets are striking sub-parallel to each other and have opposite dip directions. The foliation $\mathrm{J} 1$ dip towards the service bay area or southern end wall of the cavern and $\mathrm{J} 4$ towards the northern end wall of cavern thus forming a potential wedge. The wedge is limited by a discontinuous third joint set $\mathrm{J}_{3}$ which is oriented along the cavern alignment and steeply dipping towards the west. All the support measures have been carried out to protect the wedge failure zone.

\section{D Modeling of Powerhouse Cavern}

Geological model of Powerhouse Cavern was initially established based on 3D Geological logs of Powerhouse and its associated tunnels as well as core logs of Powerhouse executed during investigation. As per $3 \mathrm{D}$ Geological log of the overt portion of Powerhouse cavern, the litho variants of PQM, PQT and SP encountered. $88 \%$ length of cavern belongs to $\mathrm{PQM}+\mathrm{PQT}$ rock mass however $8 \%$ length belongs to PQM and PQT and rest $4 \%$ comes under PQT and SP. PQT and SP represents thinly foliated Phyllitic Quartzite with slightly to moderate weathered and sheared in nature. 50\% to $70 \% \mathrm{RQD}$, slightly rough \& rough surfaces with soft to hard filling. These properties of rock mass represent fair media for excavation.

\begin{tabular}{|c|c|c|c|}
\hline $\begin{array}{c}\text { S. } \\
\text { No. }\end{array}$ & Rock Variants & RD/Elevation & Percentages \\
\hline 1 & $\begin{array}{c}\text { PQM+PQT/ } \\
\text { PQT+PQM }\end{array}$ & $178.64 \mathrm{~m}$ & $88 \%$ \\
\hline 2 & PQM & $16.24 \mathrm{~m}$ & $8 \%$ \\
\hline 3 & PQT & $0.0 \mathrm{~m}$ & $0 \%$ \\
\hline 4 & PQT+SP & $6.09 \mathrm{~m}$ & $3 \%$ \\
\hline 5 & SP & $2.03 \mathrm{~m}$ & $1 \%$ \\
\hline
\end{tabular}

Table 7: Showing the Percentage of Rock Variants in Powerhouse Cavern

In the geological model of powerhouse, $3 \mathrm{~m}$ blasting zone around the excavation and $4 \mathrm{~m}$ at the junction were considered and homogeneous properties with disturbance factor of .3 were considered for this zone. Remaining rock mass was assigned homogeneous properties with disturbance factor of zero. Input parameter for $3 \mathrm{D}$ analysis of cavern is mentioned in Table 8.

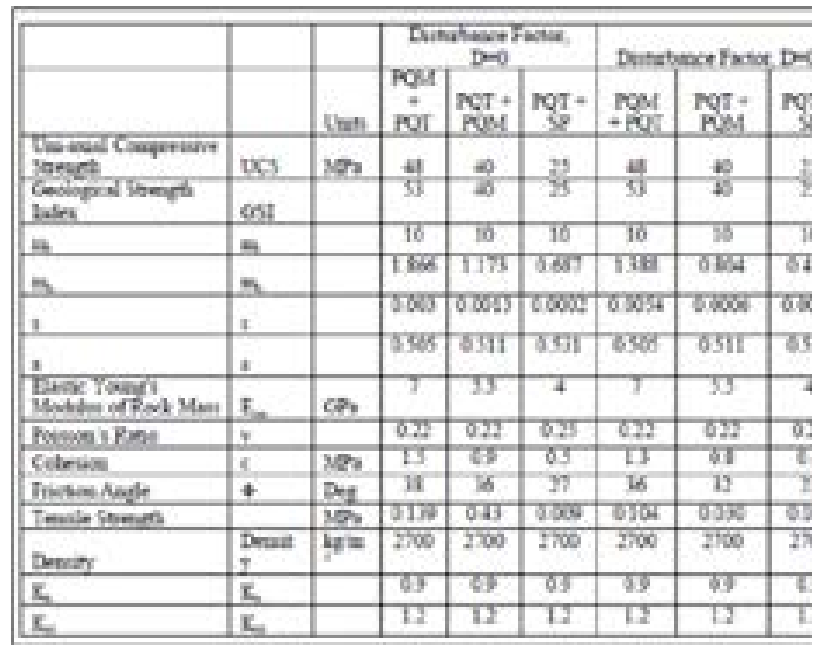

Table 8: Input Parameter for 3D analysis of Powerhouse Cavern 


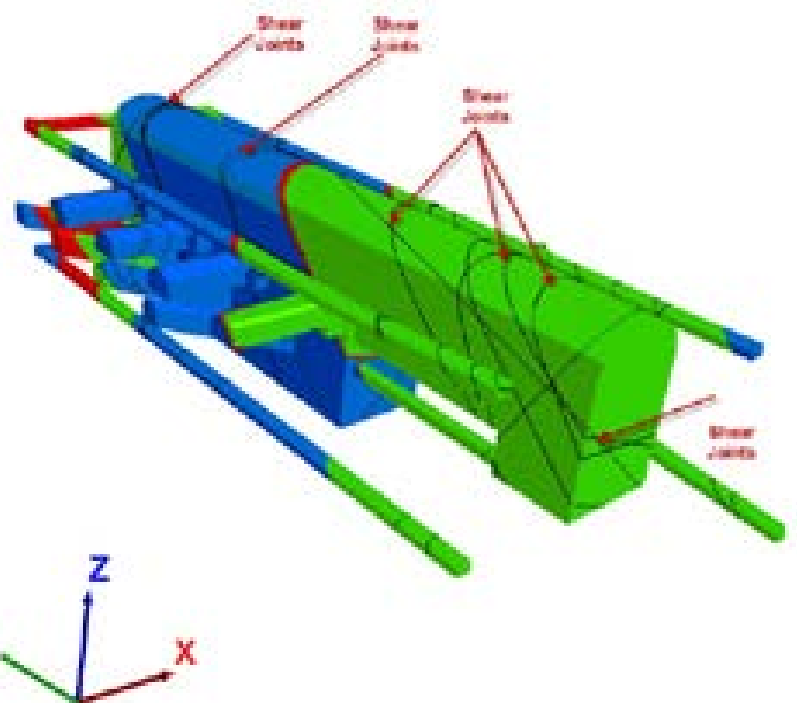

Figure 11: Showing Isometric Model of Powerhouse Cavern and its associated tunnels

\section{Construction Stage Instrumentation}

The Geotechnical instrumentation has a vital role in evaluating the structural performance of an underground structure. The natural ground or rock mass tends to deform de-stress when subjected to deformations, foundation and other loadings etc. Activities like squeezing, swelling and creeping depending upon the mechanical characteristics of the material are also responsible for the disturbance inside the underground rock mass.

The long-term performance of an underground structure is monitored by installing the structural instruments to predict and evaluate the safety of the excavated openings. However, the question on number, type and location of instruments can only be addressed by fortuitous combination of understanding the underground structural behavior, experience and judgment. The instrumentation design needs to be conceived with care and consideration of site specific conditions associated with the structure. Various type of instruments used for underground structure including system to record the key monitoring parameters listed as under,

- Convergence-Deformations of excavated surface and surrounding rock mass.

- Load developed in rock bolts and pre-stressed anchors after installation and tensioning.

- Poor water pressure in the rock mass.

- Earth pressure developed due to excavation

Multiple structures are under excavation at Tehri PSP along with several adits and tunnels. The structural behaviors of these openings have been monitored by instruments installed at respective location along the length and cross section (Figure 12).

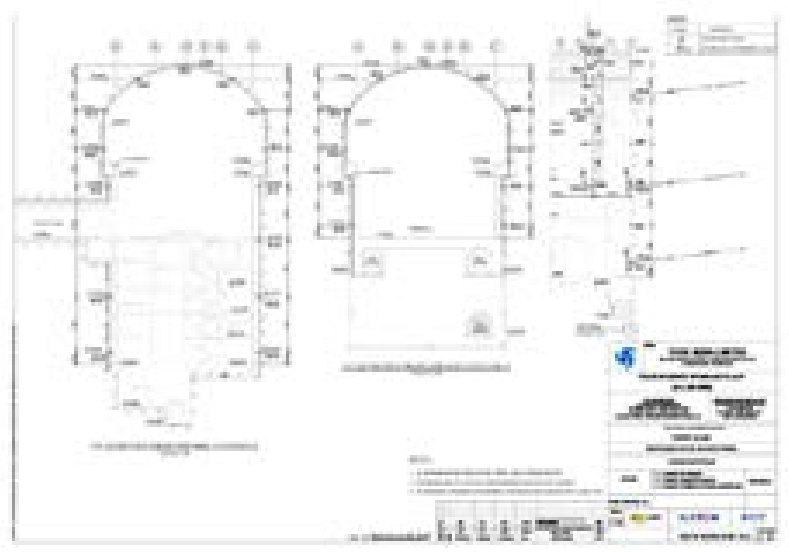

Figure 12: Showing location for the monitoring instruments in Powerhouse Cavern

\section{Bi-Reflex Targets}

Bi-Reflex Targets consists of reflector plate mounted on a robust frame. The target has reflector on both sides and is mounted on universal joint such that it can be oriented in any direction as required. The target has cross mark to allow precise targeting. It is used along with convergence bolt and break off point as shown in Figure 13. The target survey was started in May 16 for the monitoring of crown and wall movements only. The maximum target movement is observed to be $14.00 \mathrm{~mm}$ at Rd: $36.50 \mathrm{~m}$. Nominal displacements of $4.6 \mathrm{~mm}$ have also been observed at powerhouse service bay with an increase of .58mm since last month.

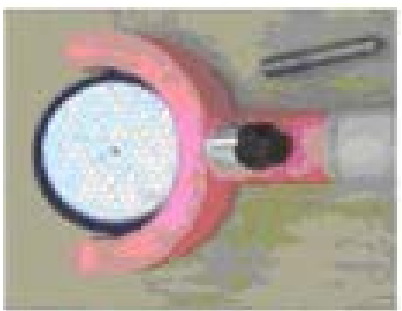

Figure 13: A Bi-Reflex Target

\section{MPBX-Multiple Point Borehole Extensometer}

The bore hole extensometer is an instrument used for monitoring movement of rock mass at several points around underground openings, rock slopes and other excavations. The instruments consists of anchors embedded in a bore hole at different depths, movement transferring elements which are fixed to the anchors and extend up to a reference head connected to bore hole collar. Each movement transferring element is covered by rigid PVC pipe, so that these elements are free to transfer the displacements of rock mass from anchor position to bore hole position. The relative displacement between the collar and movement transferring elements is measured by means of an electrical read out unit. The relative displacement is also monitored through a computerized data acquisition system for continuous logging with respect to time. The external face of collar head is used as the reference surface as shown in Figure 14. 


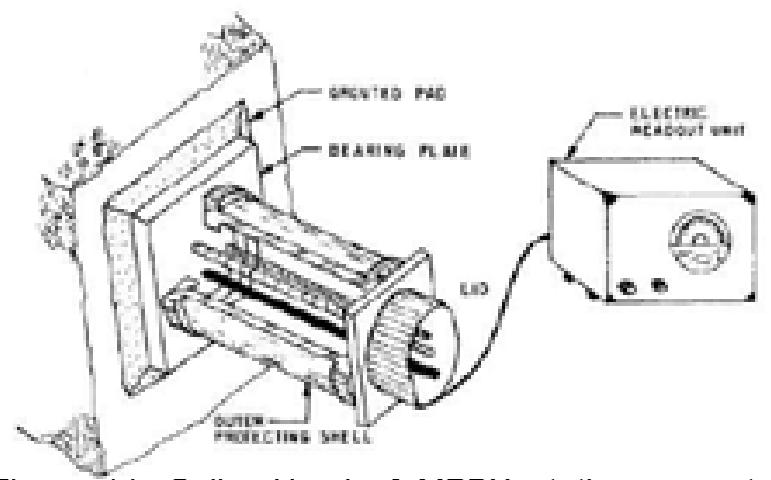

Figure 14: Collar Head of MPBX at the excavated surface

The maximum displacement in crown continues to be sensor closure of $3.66 \mathrm{~mm}$ in $5 \mathrm{~m}$ depth anchor, in crown at Rd:137.0om, MMS-1, showing no movement since last month. Similar separation values were also observed in downstream wall of powerhouse. The sensor closing is observed in MPBX sensors of crown while separation is recorded in upstream and downstream wall. This indicates that the upstream and downstream rock mass is interacting with supports and is subjected to convergence towards opening while the support in crown are relatively stable and rigid enough to restrict the movement of ground at their interface.

\section{Load Cells}

Vibrating wire load cells are used for recording and monitoring of loads in structural elements like rock bolts, tie backs, foundation anchor tunnel supports and in pre-stressing. It is installed at the time of installation of the structural elements. A pretension force is induced in the rock bolt which is recorded in the load cell. The distressing of rock mass takes place due to any excavation or loading activity and the rock load is transferred to the rock bolts. The axial load which is developed in rock bolts is reflected in load cells as an increment to the initial installed load.

The vibrating wire load cell comprises of a set of three or six vibrating wire gauges mounted parallel to each other, equally spaced in a ring in an alloy steel cylinder. The method of construction results in a very robust instrument suitable for use where high performance, longevity and a mechanical strength are important. A photograph and typical arrangement of load cells installed along with rock bolts are shown in Figure 15.

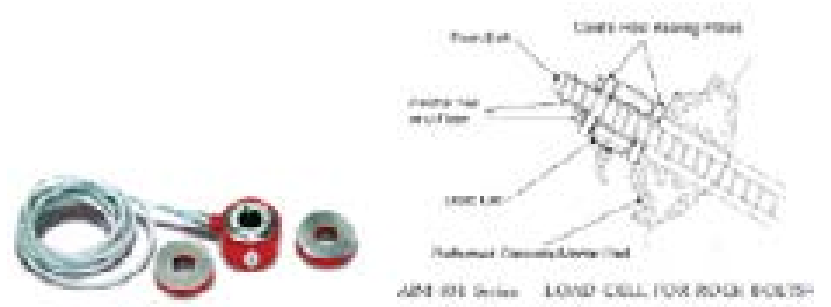

Figure 15: Load cell and its typical arrangement with Rock bolt
The monitoring of load cell is done periodically and data obtained is analyzed with the warning limits. The maximum load increment recorded in rock bolt is observed to be 9.53 Tons against the rock bolt upstream wall of powerhouse cavern at Rd:- 138 .om indicating the convergence of ground towards the opening. The rock bolt load has shown insignificant increase of .08 Tons since last month. This is much lower than the warning limit of 28 Ton in the rock bolts of dia $32 \mathrm{~mm}$.

\section{Cable Anchor load in Powerhouse Gallery}

High capacity load cells (200 Ton) are installed in the cable anchor in powerhouse upper drainage gallery (through anchor to protect crane beam) to monitor the behavior of rock mass. A decrease in load value is of 14.90 Ton and 13.30 Ton was observed in downstream and wall respectively at Rd: 135.50 and $-3.15 \mathrm{~m}$. The decrease in load or relaxation of cable anchor with respect to initial load may be due to ground divergence in Powerhouse Cavity or elongation of cable anchor.
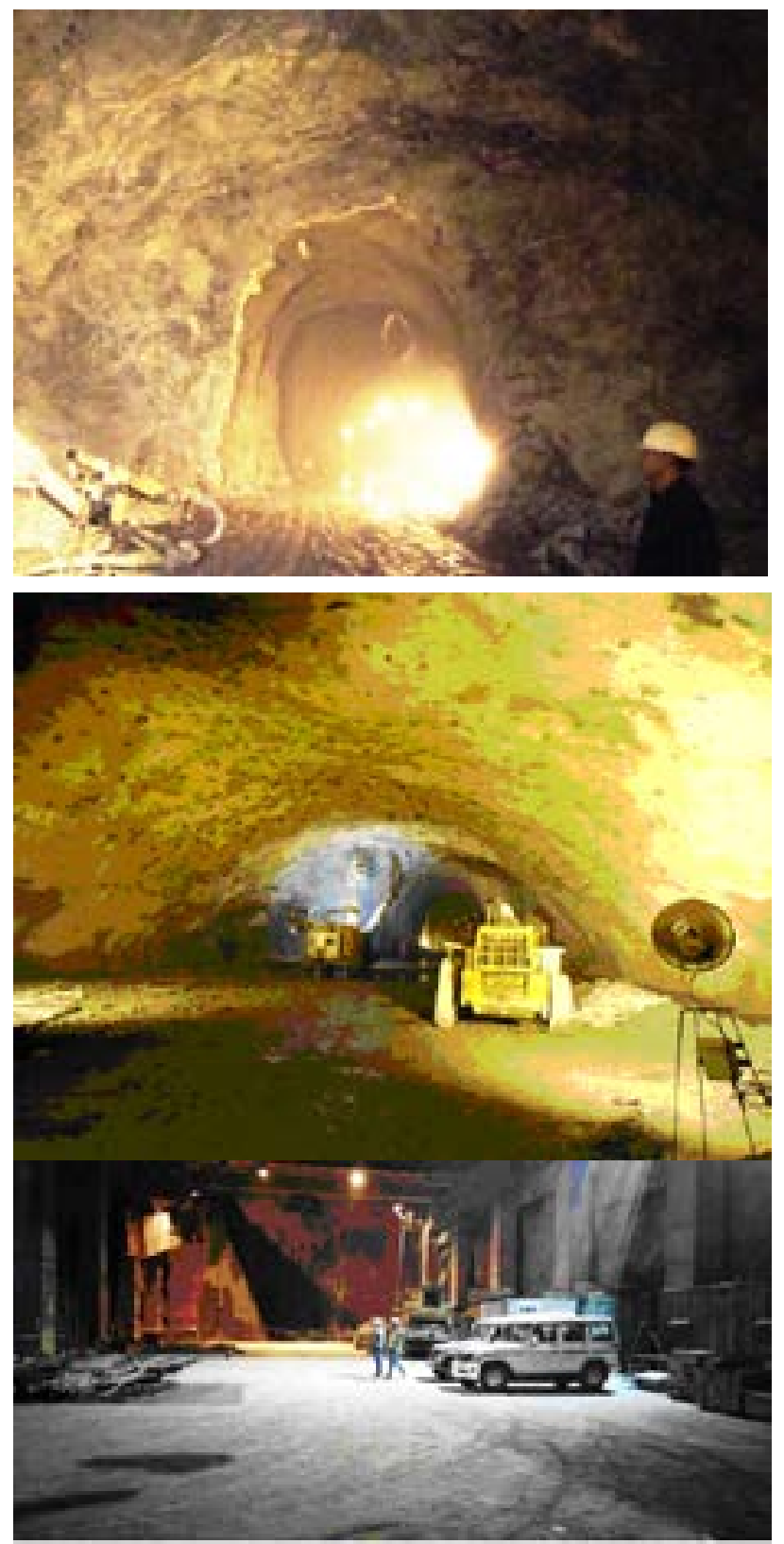


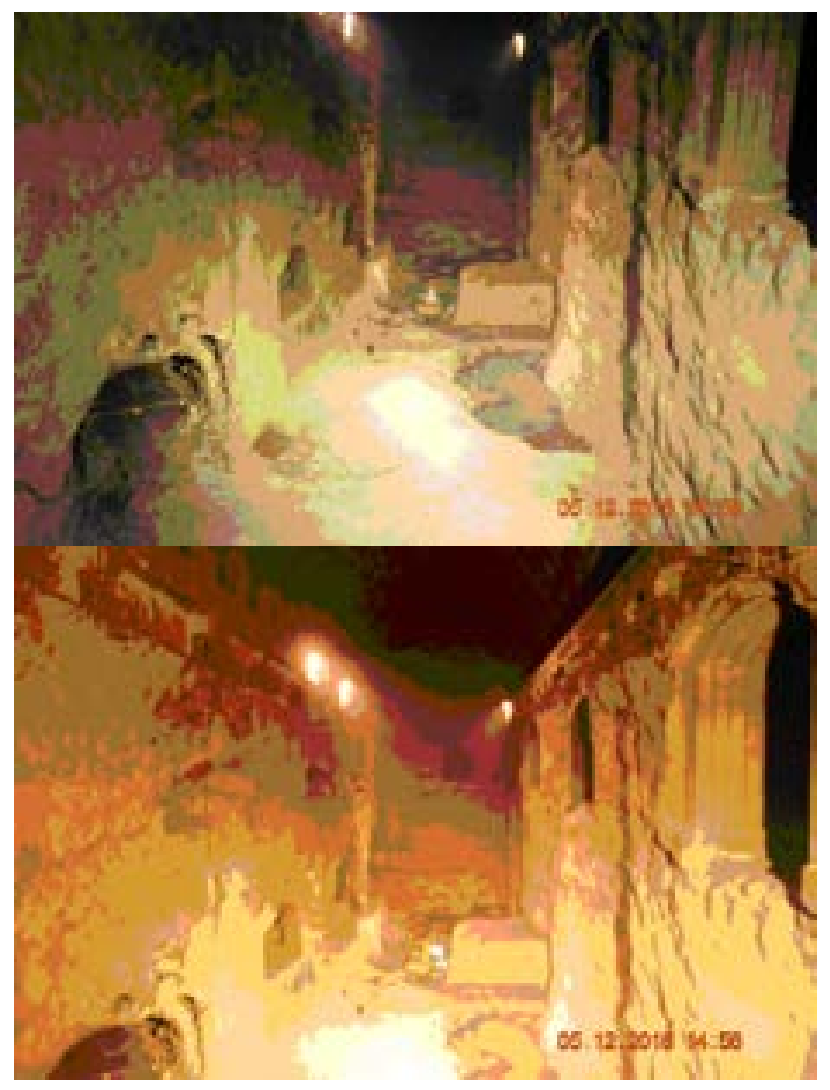

Figure 16: (A) Showing Pilot Tunnel with Slashing in Powerhouse, (B) Excavation of Heading with support , (C) Service Bay area of Powerhouse, (D \& E) Machine Hall

\section{Conclusion}

Selection of excavation methodology and design of rock support system for the treatment of adverse geology is always challenging. For successful execution of any underground structure, geological and geotechnical investigation should be given due importance while finalizing the layout and orientation. Based on geological/geotechnical investigations, abrupt changes in rock mass were least, so based on the predicted rock mass conditions excavation were executed successfully. 3D Numerical modeling studies carried out for the optimization of support system and same can be validated during construction stage based on Geotechnical instrumentation data to capture the behavior of rock mass surrounding the powerhouse cavern and also the performance of support system.

\section{Acknowledgements}

Authors are thankful to the management of THDC India Ltd. \& M/S. Hindustan Construction Co. Ltd. for providing necessary support to carry out the work.

Rajeev Prasad, Chief Geologist, Hindustan Construction Company Ltd,; Received M.Tech in Applied Geology from IIT Roorkee in 1989 and has over 28 years of multidisciplinary experience in managing large construction projects at various positions and locations in India.

Corresponding address : rpindia@hotmail.com

Nishith Sharma, Project Construction Head, Hindustan Construction Company Ltd,: Received B.E (Civil), University of Mysore 1993. PGDCM from NICMAR and has over 23 years of experience in field of large infrastructure projects in India.

\section{E-mail: sharma.nishith@rediffmail.com}

\section{Reference and Bibliography}

Babu, et al. 2018.Engineering Geological Evaluation of Rock Mass of Transformer Cavern-A case study from Lift Irrigation Project, India, Journal of TAI,Vol.7,No.2,84-91.

Bhasin, R., Barton, N., Grimstad, E., Chryssanthakis, P., 1995. Engineering geological characterization of low strength anisotropic rocks in the Himalayan region for assessment of tunnel support. Eng. Geol. 40, 169-193. doi:10.1016/0013-7952(95)ooo55-O

Bieniawski, Z.T. 1989.Engineering rock mass classification: Jhon Wiley \& Sons. New York, 272 p.

Bieniawski, Z.T. (1979). The geomechanics classification rock engineering applications. Proc. 4th Int. Congr. Rock Mech., ISRM, Montreux, 1979, vol.2, 41-48.

Bieniawski, ZT, 1978. Determining rock mass deformability, Int J. Rock Mech Min Sci, 15, 237 247.

Bieniawski, Z.T. (1973). Engineering classification of jointed rock masses. Trans. S.Afr. Inst. Civ. Eng.15,335-344.

Detailed Project Report of Tehri Pumped Storage, Unpublish Report

Gupta, Abhishek.,et.al.2015 .Sizing and Location of Underground Caverns of Powerhouse Complex-A case study of Shongtong Karcham HEP (450 MW) of HPCL. Journal of TAI,Vol.4,No.2,58-63.

Hoek, E., Diederinchs,M, S., 2006.Emperical estimation of rock mass modulus.Int.J. Rock Mech. Min.Sci.,43-215.

Jethwa, J.L., Singh, B., Singh, B., Mithal, R.S., 1980. Influence of geology on tunnling conditions and deformational behavior of supports in faulted zones - A case history of the Chhibro-Khodri tunnel in India. Eng. Geol. 16, 291-319. doi:10.1016/00137952(80)90020-4

Khanna, Rahul. Sayeed, Imran.,2016. Geotechnical Investigation for locating an Underground Powerhouse in calcareous rocks, Himachal Pradesh, India , Conference on Recent advance in Rare Engineering,141-148.

Panthi, K.K., Nilsen, B., 2007. Uncertainty analysis of tunnel squeezing for two tunnel cases from Nepal Himalaya. Int. J. Rock Mech. Min. Sci. 44, 67-76. doi:10.1016/j.ijrmms.2006.04.013

Sharma, H.R., Tiwari, A.N., 2012. Tunneling in the Himalayan region: Geological problems and solutions. Int. Water Power Dam Constr. 64, 14-19.

Unpublished Geological Report of Powerhouse Cavern of Tehri Pumped Storage 